\title{
Modification of cell volume and proliferative capacity of Pseudokirchneriella subcapitata cells exposed to metal stress
}

\author{
Manuela D. Machado ${ }^{a, b}$, Eduardo V. Soares ${ }^{a, b, *}$ \\ a Bioengineering Laboratory-CIETI, Chemical Engineering Department, ISEP-School of Engineering of Polytechnic Institute of Porto, Rua Dr António \\ Bernardino de Almeida, 431, 4200-072 Porto, Portugal \\ b IBB-Institute for Biotechnology and Bioengineering, Centre for Biological Engineering, Universidade do Minho, Campus de Gualtar, 4710-057 Braga, \\ Portugal
}

\section{A R T I C L E I N F O}

\section{Article history:}

Received 25 July 2013

Received in revised form

14 November 2013

Accepted 26 November 2013

\section{Keywords:}

Algal growth

Biovolume

Cell division

Cell proliferation

Cell size

Metal toxicity

\begin{abstract}
A B S T R A C T
The impact of metals ( $\mathrm{Cd}, \mathrm{Cr}, \mathrm{Cu}$ and $\mathrm{Zn}$ ) on growth, cell volume and cell division of the freshwater alga Pseudokirchneriella subcapitata exposed over a period of $72 \mathrm{~h}$ was investigated. The algal cells were exposed to three nominal concentrations of each metal: low (closed to $72 \mathrm{~h}-\mathrm{EC}_{10}$ values), intermediate (closed to $72 \mathrm{~h}-\mathrm{EC}_{50}$ values) and high (upper than $72 \mathrm{~h}-\mathrm{EC}_{90}$ values). The exposure to low metal concentrations resulted in a decrease of cell volume. On the contrary, for the highest metal concentrations an increase of cell volume was observed; this effect was particularly notorious for $\mathrm{Cd}$ and less pronounced for Zn. Two behaviours were found when algal cells were exposed to intermediate concentrations of metals: $\mathrm{Cu}(\mathrm{II})$ and $\mathrm{Cr}(\mathrm{VI})$ induced a reduction of cell volume, while $\mathrm{Cd}(\mathrm{II})$ and $\mathrm{Zn}(\mathrm{II})$ provoked an opposite effect. The simultaneous nucleus staining and cell image analysis, allowed distinguishing three phases in $P$. subcapitata cell cycle: growth of mother cell; cell division, which includes two divisions of the nucleus; and, release of four autospores. The exposure of $P$. subcapitata cells to the highest metal concentrations resulted in the arrest of cell growth before the first nucleus division [for $\mathrm{Cr}(\mathrm{VI})$ and $\mathrm{Cu}(\mathrm{II})]$ or after the second nucleus division but before the cytokinesis (release of autospores) when exposed to $\mathrm{Cd}(\mathrm{II})$. The different impact of metals on algal cell volume and cell-cycle progression, suggests that different toxicity mechanisms underlie the action of different metals studied. The simultaneous nucleus staining and cell image analysis, used in the present work, can be a useful tool in the analysis of the toxicity of the pollutants, in $P$. subcapitata, and help in the elucidation of their different modes of action.
\end{abstract}

(c) 2013 Elsevier B.V. All rights reserved.

\section{Introduction}

The water pollution due to the presence of metals is a wide-world problem. The anthropogenic activities are the main responsible for the contamination of the environment with metals. Industries such as energy production, battery manufacturing, mining, metallurgical and electroplating, produce effluents containing $\mathrm{Cd}(\mathrm{II}), \mathrm{Cr}(\mathrm{III}), \mathrm{Cr}(\mathrm{VI}), \mathrm{Cu}(\mathrm{II}), \mathrm{Ni}(\mathrm{II})$ and $\mathrm{Zn}(\mathrm{II})$. These effluents should be pre-treated before being discharged in rivers or oceans. Metals are not metabolically degraded. This characteristic, associated with the solubility and mobility of metals, makes their concentration and transfer through the food chain possible.

Metals exhibit short- and long-term toxic effects from microorganisms to higher organisms, including humans (Gadd, 2009). Cd,

\footnotetext{
* Corresponding author at: Bioengineering Laboratory-CIETI, Chemical Engineering Department, ISEP-School of Engineering of Polytechnic Institute of Porto, Rua Dr António Bernardino de Almeida, 431, 4200-072 Porto, Portugal. Tel.: +35122 8340500; fax: +351228321159.

E-mail address: evs@isep.ipp.pt (E.V. Soares).
}

$\mathrm{Cr}, \mathrm{Cu}$ and $\mathrm{Zn}$ affect photosynthesis of the alga Scenedesmus obliquus (Mallick and Mohn, 2003). Copper and zinc, at sublethal concentrations, inhibit photosynthesis, respiration, nitrate uptake, nitrate reductase activity and reduce the protein, carbohydrate and photosynthetic pigment levels in Scenedesmus sp. (Tripathi and Gaur, 2006). Cd, $\mathrm{Cu}$ and $\mathrm{Zn}$ produce ultrastructural changes (increase in number and volume of starch grains and vacuoles), evaluated by electron microscopy, in the alga Chlamydomonas acidophila (Nishikawa et al., 2003). Different metals [Cd(II), Cr(III), Cr(VI), $\mathrm{Cu}(\mathrm{II}), \mathrm{Pb}(\mathrm{II})$ and $\mathrm{Zn}(\mathrm{II})]$ induce the production of reactive oxygen species in Chlamydomonas reinhardtii (Szivak et al., 2009). Also Cuinduced ROS production on P. subcapitata and Chlorella vulgaris was described (Knauert and Knauer, 2008).

Short-term toxicity assays using microorganisms have gained a paramount importance in toxicity studies due to their simplicity, cost-effectiveness and reproducibility (Blaise and Férard, 2005; Wadhia and Thompson, 2007). Among the different microorganisms, microalgae are usually included in hazard assessment as representative of the aquatic community, and considered an important tool in the evaluation of physiological changes induced by metals (Torres et al., 2008). The alga P. subcapitata is particularly 
suited to toxicity testing due do it ecological relevance. In addition, it displays a higher sensitivity than invertebrates, fish and other standard test organisms to a wide range of hazardous substances, which favours its use as a reliable indicator of toxicity (Blaise et al., 1986; Geis et al., 2000).

The cell size is an essential characteristic of all organisms. It is associated with cell cycle progression and is influenced by internal and external stimuli (Bryan et al., 2012). Copper caused an increase in cell size of freshwater ( $P$. subcapitata and Chlorella sp.) and marine (Phaeodactylum tricornutum) algae (Cid et al., 1996; Franklin et al., 2001). Similarly, cadmium increased the cell volume of the alga Scenedesmus vacuolatus (Le Faucheur et al., 2005). It was also described that $\mathrm{Zn}$-treated cells of the marine diatom Nitzschia closterium were larger than control cells (Stauber and Florence, 1990). In the case of the alga Chlorella sp., copper had a bigger effect than cadmium on cell size (Franklin et al., 2002; Wilde et al., 2006).

At present, the tools that can be used for measuring cell volume are basically limited to image analysis, resistive-pulse technique (Coulter) and light scatter (Bryan et al., 2012). Flow cytometry gives the mean cell volume, based on forward light-scatter (FSC), which is dependent of the cell size and its refractive index. Generally, the larger cell size, the more forward scatter light is generated as the cell passes through a laser. Cell volume is determined assuming that all cells are spherical and have identical optical properties; deviations in cell shape and content introduce error to FSC measurements (Bryan et al., 2012). Therefore, these equipments can give erroneous results when the biovolume of nonspherical algae (Hillebrand et al., 1999), such as the alga P. subcapitata, is determined. In such algae, the determination of cell volume using microscopic measurements (by microscopic image analysis) and an appropriate mathematical equation seems to be an alternative.

Although the alga $P$. subcapitata is one of the most frequently used standard organism (American Standards for Testing Materials, American Public Health Association, Organization for Economic Cooperation and Development, International Organization for Standardization and United States Environmental Protection Agency) in toxicity tests (Janssen and Heijerick, 2003), limited information is available regarding the impact of cadmium, chromium, copper and zinc on alga morphology and proliferation capacity, despite the fact that these metals are generally present in domestic and industrial effluents.

In the present work, we have examined the impact of $\mathrm{Cd}(\mathrm{II})$, $\mathrm{Cr}(\mathrm{VI}), \mathrm{Cu}(\mathrm{II})$ and $\mathrm{Zn}(\mathrm{II})$, at different growth inhibitory concentrations on cell proliferation capacity and biovolume. Additionally, the impact of these metals on cell cycle progression of the algae P. subcapitata was evaluated.

\section{Materials and methods}

\subsection{Strain, media and culture conditions}

In this work, the freshwater green alga $P$. subcapitata (strain 278/4) was used. The original strain was obtained from the Culture Collection of Algae and Protozoa (CCAP), UK.

The algae were maintained in OECD algal test medium (OECD, 2011 ) with $20 \mathrm{~g} \mathrm{~L}^{-1}$ agar (Merck), in the dark, at $4{ }^{\circ} \mathrm{C}$. Medium stock solutions were prepared, sterilized and stored according to OECD guidelines (OECD, 2011).

The starter cultures were prepared weekly by inoculating a loop of algal cells (from agar slant) in $20 \mathrm{~mL}$ OECD medium, in $100 \mathrm{~mL}$ Erlenmeyer flasks. The cells were incubated for 2 days, at $25^{\circ} \mathrm{C}$, on an orbital shaker at $100 \mathrm{rpm}$ under continuous "cool white" fluorescent light (fluorescent lamps with a colour temperature of $4300 \mathrm{~K}$ ), with an intensity of 4000 lux at the surface of the flask, verified using an illumination meter.
The pre-cultures were prepared by inoculating $40 \mathrm{~mL}$ OECD medium, in $100 \mathrm{~mL}$ Erlenmeyer flasks with an initial cell concentration of $\sim 5 \times 10^{4}$ cells $\mathrm{mL}^{-1}$ from the starter cultures. The cells were incubated for 2 days under the conditions described above for the starter cultures.

The cultures were prepared by inoculating $400 \mathrm{~mL}$ of OECD medium in $1 \mathrm{~L}$ Erlenmeyer flasks, with an initial cell concentration of $\sim 5 \times 10^{4}$ cells $\mathrm{mL}^{-1}$ from the pre-culture, in the absence or presence of metals. Taking into account a previous study using different ranges of metals, three total nominal concentrations (for each metal) were selected as exposure concentrations. Appropriate volumes of $\mathrm{ZnCl}_{2}, \mathrm{Cu}\left(\mathrm{NO}_{3}\right)_{2}, \mathrm{CdCl}_{2}$ and $\mathrm{K}_{2} \mathrm{Cr}_{2} \mathrm{O}_{7}$ solutions were added from standard solutions (Merck) or from primary standard $\mathrm{K}_{2} \mathrm{Cr}_{2} \mathrm{O}_{7}$ solution, respectively. Cells were incubated under the conditions described above for the starter cultures for 72-96 h.

At defined intervals of time (given in the figures) samples were withdrawn and cell number determined using an automated cell counter (TC10-Bio-Rad). At low algal concentration $\left(<1 \times 10^{5}\right.$ cells $\left.\mathrm{mL}^{-1}\right)$ growth was measured by direct cell counting using a microscope and a counting chamber. Algal cell concentration was also evaluated, indirectly, by measuring the absorbance at $750 \mathrm{~nm}$, according to US-EPA (2002); a calibration curve (number of cells versus absorbance) was first constructed. For low biomass concentration it was used a cuvette with a light path of $4 \mathrm{~cm}$.

\subsection{Calculation of EC values}

The $72 \mathrm{~h}-\mathrm{EC}_{10}, 72 \mathrm{~h}-\mathrm{EC}_{50}$ and $72 \mathrm{~h}-\mathrm{EC}_{90}$ values, represent the concentration of the toxicant that caused the inhibition of $10 \%$, $50 \%$ and $90 \%$ of cell count, respectively, after $72 \mathrm{~h}$, compared to the positive control (cells not exposed to the toxicant). EC values were calculated using linear interpolation method (TOXCALC version 5.0.32, Tidepool Scientific Software).

\subsection{Calculation of specific growth rate and doubling time}

The specific growth rates $(\mu)$ were calculated by least-square fitting to the linear part of the semilogarithmic growth plots of the number of cells $\mathrm{mL}^{-1}$ versus time. The time it takes the algal population to double in cell number (doubling time or generation time) $(g)$ was calculated using the following equation:

$g=\frac{\ln 2}{\mu}$

\subsection{Cell size analysis}

Photos of non-treated (control) and treated algal cells, with the different metal concentrations, were acquired using a Leica DC $300 \mathrm{~F}$ camera and processed with Leica IM 50-Image manager software. In order to achieve accuracy in the measurement of width and length of algal cells, several photos were taken in randomly selected fields, in phase-contrast microscopy, using an N plan X100 objective.

For biovolume determination, a minimum sample size of 200 cells was used in each metal concentration and in each experiment. The cell volume was calculated based on the assumption that $P$. subcapitata generally conforms to the shape of a sickle-shaped cylinder (Sun and Liu, 2003). Cell volume $(V)$ is defined as:

$V \approx\left(\frac{\pi}{6}\right) \cdot a \cdot b^{2}$

where $a$ and $b$ are cell apical section view (length) and transapical section (width), respectively.

For each metal and concentration it was determined the frequency (i.e., the number of times) of each biovolume. 


\subsection{Nucleus staining}

Algal cells were exposed to $1.9 \mu \mathrm{molL}^{-1} \mathrm{Cd}(\mathrm{II}), 41 \mu \mathrm{mol} \mathrm{L}^{-1}$ $\mathrm{Cr}(\mathrm{VI}), 1.3 \mu \mathrm{mol} \mathrm{L}^{-1} \mathrm{Cu}$ (II) or $2.5 \mu \mathrm{mol} \mathrm{L}^{-1} \mathrm{Zn}$ (II), for $72 \mathrm{~h}$. As control, cells were grown in the absence of the metals. After metal treatment, cells were centrifuged, washed and resuspended in OECD medium at $3 \times 10^{6}$ cells $\mathrm{mL}^{-1}$. Then, cells were treated with 1-pentanol $(70 \%, v / v)$, for $1 \mathrm{~h}$, in order to permeabilize cell membrane, and stained with SYTOX Green as previously described (Machado and Soares, 2012). Briefly, algal cells were incubated with $0.5 \mu \mathrm{mol} \mathrm{L}^{-1}$ SYTOX Green, for $40 \mathrm{~min}$, at $25^{\circ} \mathrm{C}$, in the dark, and were observed using an epifluorescence microscope, equipped with a HBO-100 mercury lamp and filter set GFP from Leica. Images were acquired and processed as described above.

For the determination of cell distribution among the different phases, 200 cells were counted, in each experiment. For the determination algal biovolume, at least 75 cells were measured for each metal and cell stage.

\subsection{Reproducibility of the results and statistical analysis}

Data presented are mean values of two-four independent experiments carried out under identical conditions. Unless otherwise specified, in the legend of the figures, results were expressed as the mean \pm standard deviation, presented with $95 \%$ confidence limits. In Fig. 4, the statistical difference between control and metaltreated cells were tested using unpaired $t$ test.

\section{Results}

\subsection{Growth inhibition}

A previous study was carried out exposing algal cells for $72 \mathrm{~h}$ to seven total nominal concentrations of each metal, arranged in a geometric series, in the following ranges: $0.041-4.1 \mu \mathrm{mol} \mathrm{L}^{-1}$ $\mathrm{Cd}(\mathrm{II}), \quad 0.88-88 \mu \mathrm{mol} \mathrm{L}^{-1} \mathrm{Cr}(\mathrm{VI}), \quad 0.072-7.2 \mu \mathrm{mol} \mathrm{L}^{-1} \mathrm{Cu}(\mathrm{II})$ and $0.1-10 \mu \mathrm{mol} \mathrm{L}^{-1} \mathrm{Zn}(\mathrm{II})$. Based on this study, three total nominal concentrations were selected as exposure concentrations: a low concentration $\left(0.12 \mu \mathrm{mol} \mathrm{L}^{-1} \mathrm{Cd}, 2.7 \mu \mathrm{mol} \mathrm{L}^{-1} \mathrm{Cr}, 0.080 \mu \mathrm{mol} \mathrm{L}^{-1}\right.$ $\mathrm{Cu}$ and $0.15 \mu \mathrm{mol} \mathrm{L}^{-1} \mathrm{Zn}$ ), close to $72 \mathrm{~h}-\mathrm{EC}_{10}$ values, but where a growth inhibition was detectable; an intermediate concentration, close to $72 \mathrm{~h}-\mathrm{EC}_{50}$ values $\left(0.47 \mu \mathrm{mol} \mathrm{L}^{-1} \mathrm{Cd}, 11 \mu \mathrm{mol} \mathrm{L}^{-1}\right.$ $\mathrm{Cr}, 0.32 \mu \mathrm{mol} \mathrm{L}^{-1} \mathrm{Cu}$ and $\left.0.60 \mu \mathrm{mol} \mathrm{L}^{-1} \mathrm{Zn}\right)$ and a concentration higher than $72 \mathrm{~h}-\mathrm{EC}_{90}$ values $\left(1.9 \mu \mathrm{mol} \mathrm{L}^{-1} \mathrm{Cd}, 41 \mu \mathrm{mol} \mathrm{L}^{-1} \mathrm{Cr}\right.$, $1.3 \mu \mathrm{mol} \mathrm{L}^{-1} \mathrm{Cu}$ and $2.5 \mu \mathrm{mol} \mathrm{L}^{-1} \mathrm{Zn}$ ). The cell concentration in the control cultures (without metals) increased by a factor larger than 16 within $72 \mathrm{~h}$, and displayed a coefficient of variation less than $7 \%$, which is in agreement with the validation conditions of "alga, growth inhibition test" guidelines (OECD, 2011).
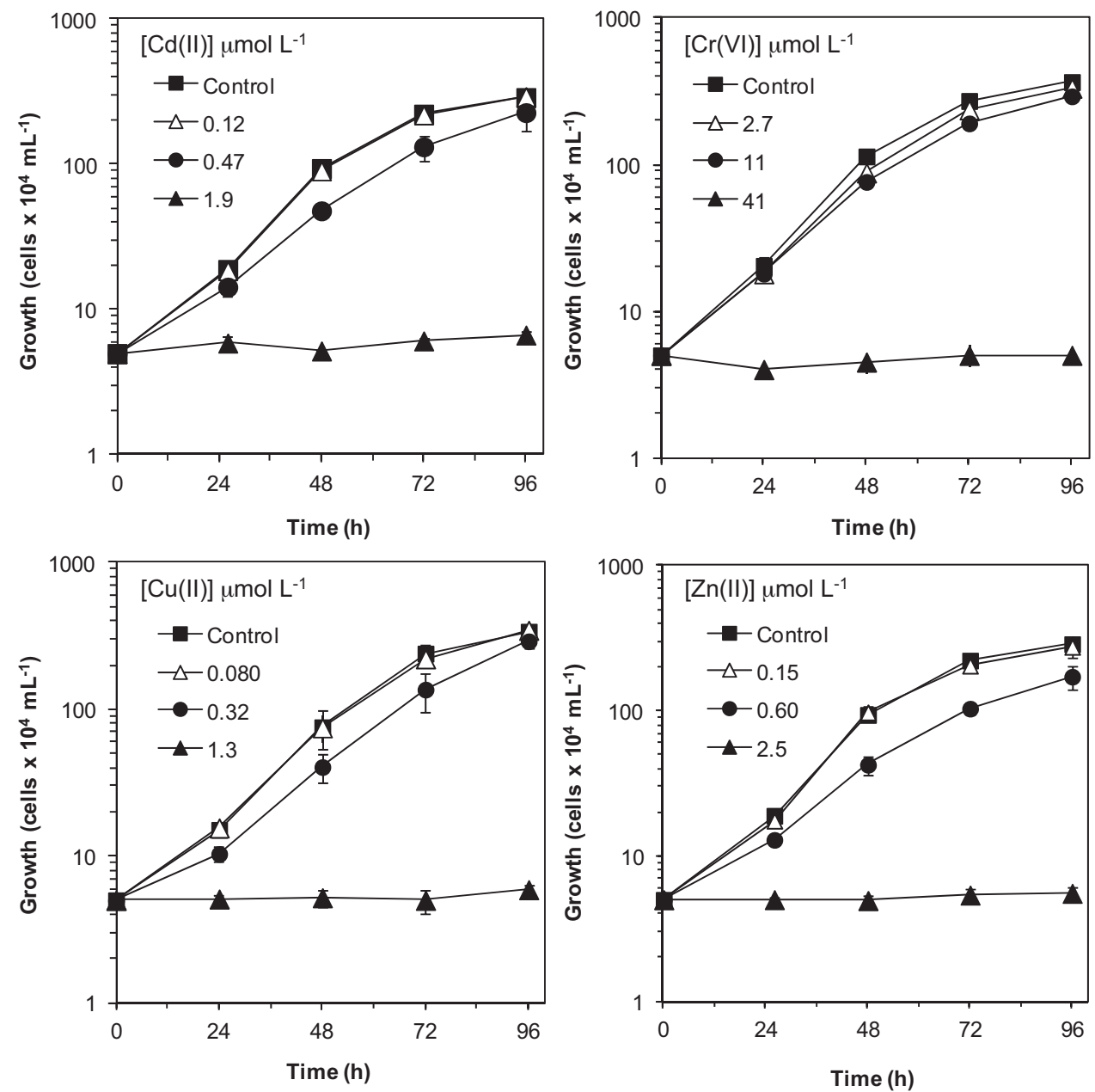

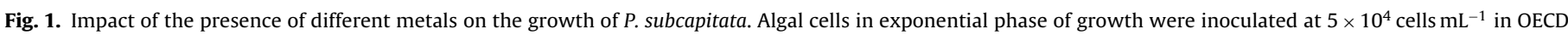

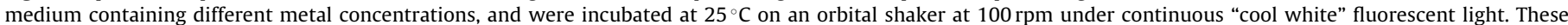

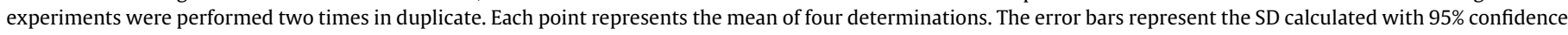
limits; where no error bars are shown they are within the points. 
The growth curves of $P$. subcapitata algal cells revealed that, with the exception of the metal concentrations corresponding to the highest values (where the growth was arrested), no important modification of latency phase was observed (Fig. 1). Control cultures (no metals added) grew exponentially during 48-72 h, with an average specific growth rate $(\mu)$ of $0.06 \mathrm{~h}^{-1}$, which corresponded to a doubling (generation) time of $\sim 12 \mathrm{~h}$, and reached the stationary phase after 72-96 h (Fig. 1). The increase of metal concentration reduced the growth rate, and consequently, increased the doubling time in a concentration-dependent manner. The exposure of algal cells to metals in a concentration closed to $\mathrm{EC}_{50}$ values caused an increase of the doubling time from $\sim 12 \mathrm{~h}$ (control cultures) to 14-16 h.

\subsection{Effect of metals on algal morphology and cell division}

The impact of metals on algal morphology was examined by microscopy image analysis. For this purpose, the width and length of algal cells grown during $72 \mathrm{~h}$, in the absence (control) or presence of metals were measured. The biovolume was calculated assuming that $P$. subcapitata generally conforms to the shape of a sickleshaped cylinder (Sun and Liu, 2003). The algal biovolumes were grouped in six classes (i.e., the cell volumes which fall within a given range) of $40 \mu \mathrm{m}^{3}$. In the case of $\mathrm{Cd}(\mathrm{II})$ an additional distribution with seven classes with a width of $80 \mu \mathrm{m}^{3}$ was considered (figure inset), due to the big increase of volume of the cells exposed to $1.9 \mu \mathrm{mol} \mathrm{L}^{-1} \mathrm{Cd}$. Fig. 2 shows the relative frequency distribution of algal biovolumes (the percentage of biovolumes falling in each class) for all the metals and concentrations studied.
Non-treated cells (control) displayed an average size (length $\times$ width) of $9.1 \times 3.2 \mu \mathrm{m}$ which corresponds to a mean cell volume of $49 \mu \mathrm{m}^{3}$. The analysis of the relative frequency distribution of population non-treated with heavy metals revealed that $>85 \%$ had a cell volume $\leq 85 \mu \mathrm{m}^{3}$ (Fig. 2). The exposure of algal cells to the lower concentrations of the metals studied, resulted in a decrease of cell volume comparatively with the control. In these conditions, $65-80 \%$ of the cells displayed a volume $<45 \mu \mathrm{m}^{3}$, while in non-treated cells, $56 \%$ presented this volume (Fig. 2). When exposed to concentrations close to $\mathrm{EC}_{50}$ values, two behaviours were found: $\mathrm{Cu}(\mathrm{II})$ and $\mathrm{Cr}(\mathrm{VI})$ induced a reduction of cell volume, while $\mathrm{Cd}(\mathrm{II})$ and $\mathrm{Zn}$ (II) provoked an opposite effect (Fig. 2). At the highest concentrations, where the growth was arrested metal-induced increase of cell volume was observed; a shift to the right of the population distribution can be seen: $30-72 \%$ of metal-treated cells had a cell volume $>85 \mu \mathrm{m}^{3}$. The increase of algal cell size is less pronounced in $\mathrm{Zn}$-treated cells. In the case of Cd-treated cells two populations were observed: one population comprised of $\sim 28 \%$ of cells with a normal morphology $\left(\leq 85 \mu \mathrm{m}^{3}\right.$ ), and another population comprised of $\sim 57 \%$ of cells with a cell volume of $165-565 \mu \mathrm{m}^{3}$ (Fig. 2, insert).

$P$. subcapitata reproduces asexually via autospores. The staining of the nucleus with SYTOX Green, combined with the measuring of cell volume allowed distinguishing three phases in P. subcapitata cell cycle: (a) growth of mother cell; (b) cell division, which includes two divisions of the nucleus; and, (c) release of four autospores (daughter cells). Four stages can be found in algal population (Fig. 3).

The determination of the biovolume of algal cells belonging to each of the 4 stages, shown in Fig. 3, revealed that cells of stage
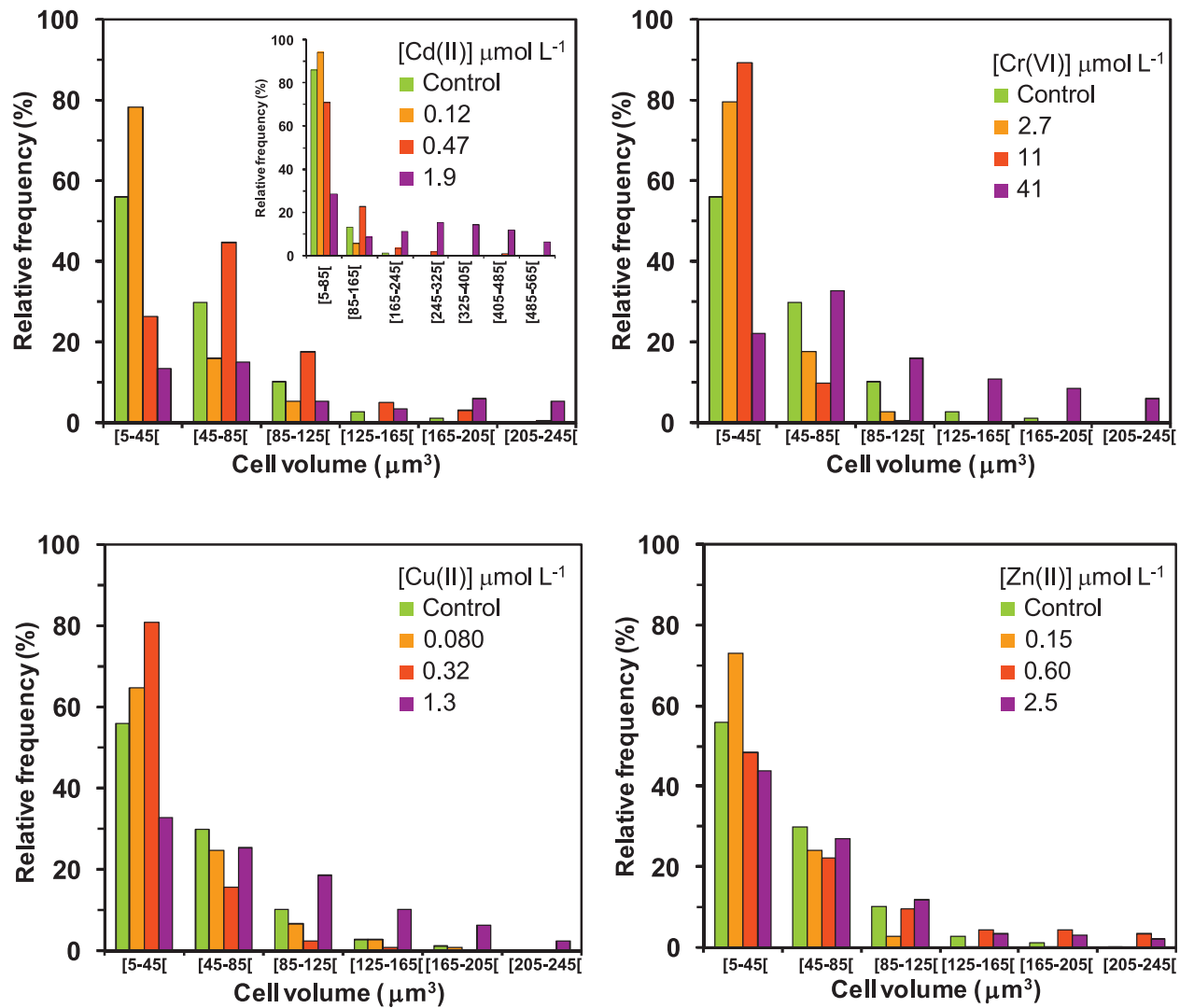

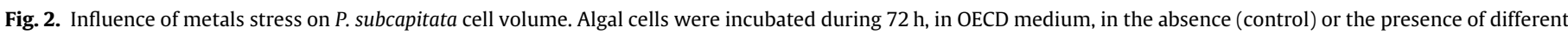

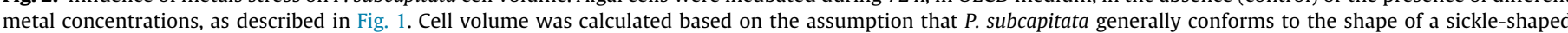

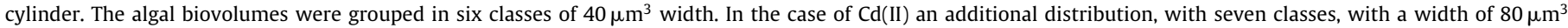

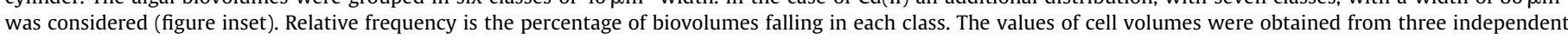
experiments. In each experiment, for each metal concentration, at least 200 cells were measured. 


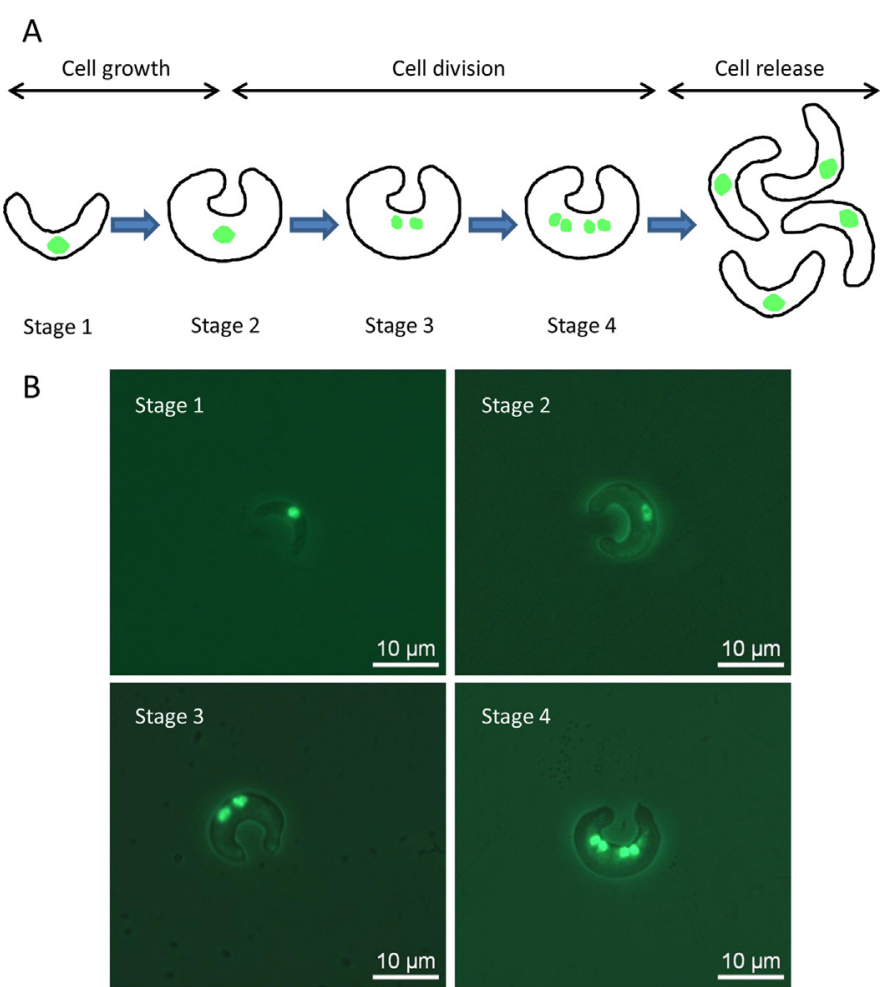

Fig. 3. Cell proliferation in P. subcapitata. (A) Diagrammatic representation of the cell cycle of the algae, which comprises of three phases: (1) growth of mother cell; (2) cell division; (3) release of daughter cells (autospores). (B) Photomicrographs of fluorescence plus phase contrast images of algal cells at different stages. For visualization of nucleus, cells were permeabilized with 1 -pentanol $(70 \%, v / v)$ for $1 \mathrm{~h}$, and subsequently stained with $0.5 \mu \mathrm{mol} \mathrm{L}^{-1}$ SYTOX Green for $40 \mathrm{~min}$.

1, 2, 3 and 4, displayed a biovolume of $22 \pm 1 \mu \mathrm{m}^{3}, 45 \pm 4 \mu \mathrm{m}^{3}$, $65 \pm 4 \mu \mathrm{m}^{3}$ and $81 \pm 6 \mu \mathrm{m}^{3}$, respectively; standard deviations were calculated with $95 \%$ confidence limits. Thus, the analysis of daughter (stage 1) and mother cell (stage 4) subpopulations in control cultures not exposed to metals, showed that the mean volume of mother cells is $\sim 4$ times higher than the mean volume of the daughter cells.

P. subcapitata algal cells, not exposed to metals (control), were mainly (55\%) in stage 1 (Fig. 4). Compared to the control, algal cells exposed to the highest values of $\mathrm{Cd}(\mathrm{II}), \mathrm{Cr}(\mathrm{VI})$ and $\mathrm{Zn}(\mathrm{II})$ displayed a very significantly different $(P<0.01)$ stage distribution. $\mathrm{Cr}(\mathrm{VI})$ and $\mathrm{Cu}$ (II)-treated cells were accumulated mainly ( $50 \%)$ in stage 2 and $\mathrm{Cd}(\mathrm{II})$-treated cells in stage 4 (60\% of the cells). In the case of $\mathrm{Zn}(\mathrm{II})$, the distribution through the different cell cycle stages did not differ very significantly $(P<0.01)$ from the control (Fig. 4$)$. These results strongly suggest that cell growth of $\mathrm{Cr}(\mathrm{VI})$ and $\mathrm{Cu}(\mathrm{II})$-treated cells was arrested before the first division, while cell growth in $\mathrm{Cd}(\mathrm{II})$ treated cells was arrested before the release of the daughter cells.

\section{Discussion}

The chlorophyte (green alga) P. subcapitata is unicellular, non motile, easily cultivated in the laboratory, representative of eutrophic and oligotrophic freshwater environments and displays a higher sensitivity to a variety of hazardous substances (Blaise and Vasseur, 2005). These characteristics make this alga well suited for to be used as cell model in toxicity studies.

In the present work, the impact of three nominal concentrations of different metals ( $\mathrm{Cd}, \mathrm{Cr}, \mathrm{Cu}$ and $\mathrm{Zn}$ ), usually used as reference toxicants (Blaise and Vasseur, 2005; US-EPA, 2002), on proliferation capacity, biovolume, and cell cycle progression of the algae $P$. subcapitata was studied.

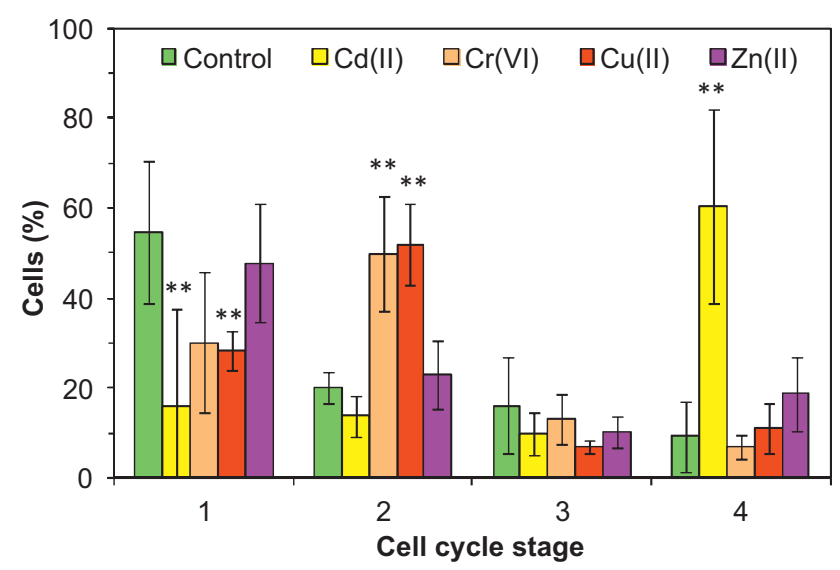

Fig. 4. Distribution of $P$. subcapitata algal cells through the cell cycle. The algal cells were incubated in the absence (control) or the presence $1.9 \mu \mathrm{mol} \mathrm{L}^{-1} \mathrm{Cd}$ (II), $41 \mu \mathrm{mol} \mathrm{L}^{-1} \mathrm{Cr}(\mathrm{VI}), 1.3 \mu \mathrm{mol} \mathrm{L}^{-1} \mathrm{Cu}(\mathrm{II})$ or $2.5 \mu \mathrm{mol} \mathrm{L}^{-1} \mathrm{Zn}(\mathrm{II})$, for $72 \mathrm{~h}$, as described in Fig. 1. The cell cycle stages considered are presented in Fig. 3. Values are obtained from three independent experiments. In each experiment, for each metal, at least 200 cells were measured. The error bars represent the SD calculated with $95 \%$ confidence limits. For each cell cycle stage statistical differences between control and metal-treated cells were tested using unpaired $t$ test. The means with $\left(^{* *}\right)$ are very significantly different $(P<0.01)$ from the control.

Non-treated cells (control) displayed an average size (length $\times$ width) of $9.1 \times 3.2 \mu \mathrm{m}$ which corresponds to a mean cell volume of $49 \mu \mathrm{m}^{3}$; these values are within the range described by $O E C D$, measured with electronic particle counter: cell size (length $\times$ width) of 8-14 $\times 2-3 \mu \mathrm{m}$ and a cell volume of $40-60 \mu \mathrm{m}^{3}$ (OECD, 2011). Algal cell volume changed due to the presence of metals. Thus, algal cells exposed to lower concentrations of $\mathrm{Cd}$, $\mathrm{Cr}$, $\mathrm{Cu}$ and $\mathrm{Zn}$ reduced their cell volume (Fig. 2). An intermediary behaviour (reduction for $\mathrm{Cr}$ and $\mathrm{Cu}$ and increase of cell volume for $\mathrm{Cd}$ and $\mathrm{Zn}$ ) was found in the exposure to intermediary concentrations, close to $72 \mathrm{~h}-\mathrm{EC}_{50}$ values. The highest exposure concentrations of $\mathrm{Cd}, \mathrm{Cr}, \mathrm{Cu}$ and $\mathrm{Zn}$ resulted in an increase of cell volume (Fig. 3). Franklin et al. (2001), also described a copper concentration-dependent increase in cell size of $P$. subcapitata evaluated by flow cytometry, based on forward light-scatter. In the present work, a detailed analysis of cell population, exposed to different metal concentrations was carried out by microscopic image analysis, making it possible to evaluate subtle metal-induced changes of cell volume. These results showed that the presence of metals, although at sub-inhibitory concentrations, can modify algal cell volume.

The classical model of the cell-division cycle comprises the following phases: G1 (cells increase in size), S (DNA replication), G2 (gap between DNA synthesis and mitosis) and M (mitosis) (Smith and Fornace, 1996). Eukaryotic organisms present control points in the cell cycle. One of these checkpoints in unicellular algae is related with the attainment of a critical cell volume, an equivalent to START in budding yeasts (Vitova and Zachleder, 2005). In fact, the control of cell volume is a determining issue in the regulation of cell cycle in order to maintain the cell size (Oldenhof et al., 2004). C. vulgaris (Rioboo et al., 2009) and C. reinhardtii (Matsumura et al., 2003) algal cells grow during G1 phase until duplicating their size; after reaching a critical threshold size, algal cells begin to divide. A similar observation was done in P. subcapitata (Fig. 3). It was found that mother cells (stage 4), in control cultures, displayed a volume $\sim 4$ times higher than daughter cells (stage 1 ). The nuclear staining combined with the cell measurement allowed discriminating different cell stages within a population of $P$. subcapitata and perform the analysis of the volume of each subpopulation.

In the case of the algal cells that divide by multiple fission, resulting in 4 or 8 daughter cells, such as Scenedesmus quadricauda, the 
growth is associated with more than one checkpoint within the cell cycle (Hlavova et al., 2011). In these cells multiple DNA replications, nuclear division rounds and, at the end, a multiple cleavage of the cell occur (Hlavova et al., 2011). Due to the fact that nuclear and cellular division are temporally separated during cell cycle progression, it was suggested that there is a gap phase, called G3, between nuclear and cell division (Zachleder et al., 1997). The division process in P. subcapitata includes two divisions of the nucleus (Fig. 3). Thus, algae cell cycle can be arrested in two or more points when exposed to toxicants. Consistent with this possibility, the exposure of asynchronous cultures of $P$. subcapitata to metals resulted in the stop of the growth at different cell division stages. As can be observed from Fig. 4, the exposure of algal cells to the highest $\mathrm{Cr}(\mathrm{VI})$ and $\mathrm{Cu}$ (II) concentrations resulted in the accumulation of cell population in stage 2, before the first nuclear division. Cells exposed to $\mathrm{Cd}(\mathrm{II})$ accumulated in cell stage 4 , after the second nucleus division but before the cytokinesis (release of daughter cells).

In conclusion, morphological alterations of the alga P. subcapitata were observed when the algae were exposed for $72 \mathrm{~h}$ to sub-inhibitory, and, particularly, inhibitory growth concentrations of $\mathrm{Cd}(\mathrm{II}), \mathrm{Cr}(\mathrm{VI})$ and $\mathrm{Cu}(\mathrm{II})$. The simultaneous nuclei staining and cell image analysis allowed assessing the impact of metal pollutants on cell morphology and cell cycle progression, which can be helpful to identify and elucidate the different modes of action of pollutants, in P. subcapitata exposed to chronic or acute toxicity.

\section{Acknowledgments}

The authors thank the Fundação para a Ciência e a Tecnologia (FCT) through the Portuguese Government for their financial support of this work through the strategic project-LA23/2013-2014 to IBB. Manuela D. Machado gratefully acknowledges the postdoctoral grant from FCT (SFRH/BPD/72816/2010).

\section{References}

Blaise, C., Férard, J.-F., 2005. Overview of contemporary toxicity testing. In: Blaise, C., Férard, J.F. (Eds.), Small-scale Freshwater Toxicity Investigations. Springer, Dordrecht, The Netherlands, pp. 1-68.

Blaise, C., Legaut, R., Bermingham, R., Coillie, V., Vasseur, P., 1986. A simple microplate algal assay technique for aquatic toxicity assessment. Toxicity Assessment 1,261-281.

Blaise, C., Vasseur, P., 2005. Algal microplate toxicity test. In: Blaise, C., Férard, J.-F. (Eds.), Small-scale Freshwater Toxicity Investigations. Springer, pp. 137-179.

Bryan, A.K., Engler, A., Gulati, A., Manalis, S.R., 2012. Continuous and long-term volume measurements with a commercial coulter counter. PLoS One 7, 1-8.

Cid, A., Fidalgo, P., Herrero, C., Abalde, J., 1996. Toxic action of copper on the membrane system of a marine diatom measured by flow cytometry. Cytometry 25, 32-36.

Franklin, N.M., Stauber, J.L., Lim, R.P., 2001. Development of flow cytometry-based algal bioassays for assessing toxicity of copper in natural waters. Environmental Toxicology and Chemistry 20, 160-170.

Franklin, N.M., Stauber, J.L., Lim, R.P., Petocz, P., 2002. Toxicity of metal mixtures to a tropical freshwater alga (Chlorella sp.): the effect of interactions between copper, cadmium, and zinc on metal cell binding and uptake. Environmental Toxicology and Chemistry 21, 2412-2422.

Gadd, G.M., 2009. Heavy metal pollutants: environmental and biotechnological aspects. In: Schaechter, M. (Ed.), Encyclopedia of Microbiology. Elsevier, Oxford, pp. 321-334.
Geis, S.W., Fleming, K.L., Korthals, E.T., Searle, G., Reynolds, L., Karner, D.A., 2000 Modifications to the algal growth inhibition test for use as a regulatory assay. Environmental Toxicology and Chemistry 19, 36-41.

Hillebrand, H., Durselen, C.D., Kirschtel, D., Pollingher, U., Zohary, T., 1999. Biovolume calculation for pelagic and benthic microalgae. Journal of Phycology 35, 403-424.

Hlavova, M., Cizkova, M., Vitova, M., Bisova, K., Zachleder, V., 2011. DNA damage during $\mathrm{G} 2$ phase does not affect cell cycle progression of the green alga Scenedesmus quadricauda. PLoS One 6, 1-13.

Janssen, C.R., Heijerick, D.G., 2003. Algal Toxicity Tests for Environmental Risk Assessments of Metals, Reviews of Environmental Contamination and Toxicology. Springer, New York, pp. 23-52.

Knauert, S., Knauer, K., 2008. The role of reactive oxygen species in copper toxicity to two freshwater green algae. Journal of Phycology 44, 311-319.

Le Faucheur, S., Behra, R., Sigg, L., 2005. Phytochelatin induction, cadmium accumulation, and algal sensitivity to free cadmium ion in Scenedesmus vacuolatus. Environmental Toxicology and Chemistry 24, 1731-1737.

Machado, M.D., Soares, E.V., 2012. Development of a short-term assay based on the evaluation of the plasma membrane integrity of the alga Pseudokirchneriella subcapitata. Applied Microbiology and Biotechnology 95, 1035-1042.

Mallick, N., Mohn, F.H., 2003. Use of chlorophyll fluorescence in metal-stress research: a case study with the green microalga Scenedesmus. Ecotoxicology and Environmental Safety 55, 64-69.

Matsumura, K., Yagi, T., Yasuda, K., 2003. Role of timer and sizer in regulation of Chlamydomonas cell cycle. Biochemical and Biophysical Research Communications 306, 1042-1049.

Nishikawa, K., Yamakoshi, Y., Uemura, I., Tominaga, N., 2003. Ultrastructural changes in Chlamydomonas acidophila (Chlorophyta) induced by heavy metals and polyphosphate metabolism. FEMS Microbiology Ecology 44, 253-259.

OECD, 2011. Alga, Growth Inhibition Test (201). OECD Guideline for Testing of Chemicals. Organization for Economic Co-operation and Development, Paris, France.

Oldenhof, H., Bisova, K., van den Ende, H., Zachleder, V., 2004. Effect of red and blue light on the timing of cyclin-dependent kinase activity and the timing of cell division in Chlamydomonas reinhardtii. Plant Physiology and Biochemistry 42 , 341-348.

Rioboo, C., O’Connor, J.E., Prado, R., Herrero, C., Cid, A., 2009. Cell proliferation alterations in Chlorella cells under stress conditions. Aquatic Toxicology 94 229-237.

Smith, M.L., Fornace, A.J., 1996. Mammalian DNA damage-inducible genes associated with growth arrest and apoptosis. Mutation Research-Reviews in Genetic Toxicology 340, 109-124.

Stauber, J.L., Florence, T.M., 1990. Mechanism of toxicity of zinc to the marine diatom Nitzschia closterium. Marine Biology 105, 519-524.

Sun, J., Liu, D.Y., 2003. Geometric models for calculating cell biovolume and surface area for phytoplankton. Journal of Plankton Research 25, 1331-1346.

Szivak, I., Behra, R., Sigg, L., 2009. Metal-induced reactive oxygen species production in Chlamydomonas Reinhardtii (Chlorophyceae). Journal of Phycology 45 427-435.

Torres, M.A., Barros, M.P., Campos, S.C.G., Pinto, E., Rajamani, S., Sayre, R.T., Colepicolo, P., 2008. Biochemical biomarkers in algae and marine pollution: a review. Ecotoxicology and Environmental Safety 71, 1-15.

Tripathi, B.N., Gaur, J.P., 2006. Physiological behavior of Scenedesmus sp. during exposure to elevated levels of $\mathrm{Cu}$ and $\mathrm{Zn}$ and after withdrawal of metal stress. Protoplasma 229, 1-9.

US-EPA, 2002. Short-term Methods for Estimating the Chronic Toxicity of Effluents and Receiving Waters to Freshwater Organisms, 4th ed. Environmental Protection Agency, Washington, DC, pp. 1-350, EPA-821-R-02-013.

Vitova, M., Zachleder, V., 2005. Points of commitment to reproductive events as a tool for analysis of the cell cycle in synchronous cultures of algae. Folia Microbiologica 50, 141-149.

Wadhia, K., Thompson, K.C., 2007. Low-cost ecotoxicity testing of environmental samples using microbiotests for potential implementation of the water framework directive. TrAC-Trends in Analytical Chemistry 26, 300-307.

Wilde, K.L., Stauber, J.L., Markich, S.J., Franklin, N.M., Brown, P.L., 2006. The effect of $\mathrm{pH}$ on the uptake and toxicity of copper and zinc in a tropical freshwater alga (Chlorella sp.). Archives of Environmental Contamination and Toxicology 51, 174-185.

Zachleder, V., Schlafli, O., Boschetti, A., 1997. Growth-controlled oscillation in activity of histone H1 kinase during the cell cycle of Chlamydomonas reinhardtii (Chlorophyta). Journal of Phycology 33, 673-681. 